IJORER : International Journal of Recent Educational Education Homepage : https://journal.ia-education.com/index.php/ijorer Email : ijorer@ia-education.com
p-ISSN : 2721-852X ; e-ISSN : 2721-7965 IJORER, Vol. 1, No. 3, October $2020: 233-245$ (C) 2020 IJORER : International Journal of Recent Educational Education

\title{
Implementation of Islamic Senior High School Academic Quality Assurance (Multi-Site Study at Islamic Senior High School of Surabaya and Islamic Senior High School of 2 Malang)
}

*Andiek Widodo' ${ }^{1}$, Yatim Riyanto ${ }^{2}$, Erni Roesminingsih ${ }^{3}$

1,2,3 Doctoral Program of Education Management, Universitas Negeri Surabaya, Surabaya, Indonesia

\begin{tabular}{|c|c|}
\hline (A) Check for updates open $\partial_{\text {access }}$ C) (i) () & DOI : https://doi.org/10.46245/ijorer.v1i3.61 \\
\hline Sections Info & ABSTRACT \\
\hline Article history: & This study aims to examine the implementation of academic quality \\
\hline Submitted: September 5, 2020 & assurance, as well as the strategies and models used in improving \\
\hline Final Revised: October 22, 2020 & academic quality assurance in the Islamic Senior High School of Surabaya \\
\hline Accepted: October 22, 2020 & and Islamic Senior High School of 2 Malang. This study used a qualitative \\
\hline Published Online: October 31, 2020 & approach with a multi-site research design. Based on the results of the \\
\hline Keywords: & research that has been done, it is concluded that the implementation of \\
\hline Academic & academic quality assurance in the process of implementing education at \\
\hline Education & Madrasahs has been carried out well in improving the quality of learning, \\
\hline Multi-Site Study & academic achievement, and competitiveness of these madrasah \\
\hline Quality Assurance & graduates. The implementation of quality assurance can be done using \\
\hline 口inition & $\begin{array}{l}\text { the first strategy, the leadership has given trust and responsibility in } \\
\text { implementing management guidelines, second, the madrasah activity } \\
\text { program is socialized intensively, and third, the preparation of learning } \\
\text { tools that are carried out collaboratively. Overall, the implementation of } \\
\text { madrasah academic quality assurance has been carried out according to } \\
\text { national education standards. }\end{array}$ \\
\hline
\end{tabular}

\section{INTRODUCTION}

Education for every nation is a long-term investment in the development of a better future. Education is a basic human need (Sulaiman \& Wibowo, 2016). This is very strategic in shaping the quality of citizens who play a role in filling global development (Suwardani, 2010). The quality of education is not only seen from the splendor of educational infrastructure but the extent to which graduates of an educational institution can become competent human beings (Darmaji, 2019) and have quality in their fields. This needs to be done so that academic quality assurance is by national education standards (Haryono et al., 2019). The National Education System states that the National Education System is an integrated whole component to achieve the goals of national education, namely to develop capabilities and improve the quality of life and dignity of Indonesian people as a whole.

Every human resource in educational units, both schools, and madrasahs on the formal and non-formal channels, is required to ensure the quality of education (Nuraeni, 2010). All parties involved in educational institutions are required to contribute to systematically ensuring the quality of education (Nawawi, 2020), integrated and sustainable to develop good professionalism, have high achievement, and are highly competitive both in and outside of learning (Sukandari, 2016). Based on data obtained from the Institutional sector of the Regional Office of the Ministry of Religion, East Java, the current number of Islamic High School in East Java is 1.640 with private status and 90 schools with state status. 
Implementation of Islamic Senior High School Academic Quality Assurance (Multi-Site Study at Islamic Senior High School of Surabaya and Islamic Senior High School of 2 Malang)

Based on the category of the number of known data, the accreditation achievements of Madrasahs in East Java were also obtained. These results show that only $17 \%$ of the madrasah accredited "A". This percentage implies that out of a total of 1640 Islamic Senior High School in East Java, there are around 251 Islamic Senior High School that have been accredited A. This figure is certainly still low if you look at the total number of Islamic Senior High School in East Java. The achievement of accreditation is an indicator of the quality of education, so that it is still far from the ideal condition for realizing high-quality madrasas. All parties involved in educational institutions are required to contribute systematically in ensuring the quality of education (Nawawi, 2020), integrated and sustainable to develop good professionalism, have high achievements, and are highly competitive both in and outside of learning (Sukandari, 2016). In this case, teacher development and evaluation is needed (Aelterman et al., 2013; Goldhaber, 2015). Meanwhile, the number of State Islamic Senior High School (MA) in East Java accredited A is 85 School, and that accredited B are 5 State Islamic Senior High School of the total State Madrasah Aliyah or State Islamic Senior High School. With this condition, the quality assurance system is very important to be implemented completely (Oztas, 2017). Implementing quality assurance will ensure the quality of every madrasah activity, namely the input, process, and output of madrasah management (Odongo, 2017), So the quality of teaching is important (Gore \& Bowe, 2015; Hill et al., 2013; Kennedy, 2014)

Based on the preliminary studies that have been carried out including school accreditation, national exam results, community image, student achievement, and output results, it provides an analysis that conditions are not the same between one school and another. Some Islamic Senior High School are categorized as good with good student abilities as well (Oztas, 2017), even becoming a reference at the provincial level, but some must continue to develop. The difference in achievement needs service quality that must be guaranteed by internal and external audits (Handayani \& Pujiono, 2017).

School in improving the quality of education are organized independently and strategically (Suryaningsih \& Imron, 2019), referring to a national policy framework that is supported by the provision of adequate input, has responsibility for developing its resources according to the learning needs of students and society (Nuraeni, 2020). From various cases of implementation of quality assurance in different objects, researchers will dig in-depth to construct the implementation of ideal academic quality assurance in madrasah based on data and research findings.

Referring to the above problem, this research has a strategic position in scientific studies of quality assurance that exist in both Madrasah, examining how to implement academic quality assurance, and how strategies and models are used in improving academic quality assurance at Islamic Senior High School Surabaya and Islamic Senior High School 2 Malang.

The focus of this research is to specifically find a model of quality assurance implementation with inductive analysis based on research data at Islamic Senior High School of Surabaya and Islamic Senior High School of 2 Malang. An inductive approach is an approach by drawing a general conclusion from various real facts obtained from the research locus (Sugiyono, 2018). 


\section{RESEARCH METHOD \\ General Background}

The approach in research that will be carried out uses a qualitative approach or often referred to as a naturalistic approach (Suwardani, 2010). The qualitative approach is research to describe the object of research naturally (Sugiyono, 2018). This research was designed to obtain and describe the data as a whole and intact by carrying out important steps regarding the implementation of Islamic senior high school quality assurance. The research design to be carried out is multi-site, multi-site research is a qualitative research design involving several sites (Suwardani, 2010). This is by the design in the study, which is carried out in the same place and has the same characteristics.

\section{Procedure of Research}

The research procedure used includes 3 processes. First, through the process of collecting data and condensation, namely data obtained from interviews or documentation analyzed and selected important points for the content. Second, the process of presenting data is the process of displaying data in a simple form which is arranged into sentences. Third, the process of leveraging or concluding, namely the process of extracting the essence of the data.

\section{Participants}

The research subjects used in this study consisted of 2 Officials in the Regional Office (Kanwil) of the Ministry of Religion of East Java Province, 2 Madrasah principals, Deputy Head of Madrasahs, and Madrasah Teachers in both Islamic Senior High School who were directly the research subjects.

\section{Data Collection}

Collecting data in this study used four data collection methods, namely; 1) Human Instruments (Human Instrument), 2) In-depth interviews, 3) Participant observation, 4) Study of documents. These four methods will be discussed in detail regarding the four techniques, namely in-depth interviews, participant observation, and documentation study.

\section{Data and Analysis}

This study uses two types of data analysis, namely on-site data analysis and cross-site data (Miles \& Saldana, 2014). Data analysis on the site in this study is an analysis of data at each Islamic Senior High Scholl which is used as a research site for Islamic Senior High School of Surabaya and Islamic Senior High School of 2 Malang. Meanwhile, cross-site data analysis is a process of comparing findings obtained from each site, as well as integrating findings between sites.

\section{RESULTS AND DISCUSSION}

After conducting interviews, observations, and in-depth studies on quality assurance of the two Madrasahs, several interviews were obtained that were given by research participants. The implementation of academic quality assurance at Islamic Senior High School of Surabaya has been going well but there are still challenges that must be faced to exceed what is stipulated in the National Education Standards. This challenge must 
Implementation of Islamic Senior Hight School Academic Quality Assurance (Multi-Site Study at Islamic Senior High School of Surabaya and Islamic Senior High School of 2 Malang)

be resolved because the existing conditions require immediate improvement, as stated by the Head of Islamic Senior High School of Surabaya, Fathurrahman as follows.

"The implementation of academic quality assurance at Islamic Senior High School of Surabaya has been going well, but many things must be addressed to make the quality of education better, so I, together with the deputy head of madrasah, are trying to make improvements by inviting all students, teachers and staff educators committed together to lead to the better".

Based on data from in-depth interviews, it can be explained that the implementation of quality assurance continues to be made with academic improvements carried out in collaboration with all deputy heads of the Islamic Senior High School of Surabaya, educators, and education staff to continue to carry out better education. This is in line with the research of Mulyasa et al., (2018) states that ensuring the quality of education at the Nusantara Islamic University is a continuous process of improving the quality of the education process through various activities and joint evaluation control.

The implementation of this academic quality assurance is also supported by several efforts made by national education standards, as explained by Mrs. Neni Suhartini as Deputy Head of the Curriculum to conduct various socialization program activities that support the achievement of National Education Standards.

"To support the implementation of academic quality assurance at MAN Surabaya, we have carried out the habituation of Dhuha prayer for students, Fardlu prayer, congregational praying during learning, and various habituation of other religious activities."

From interviews conducted in-depth, information was also obtained that so far supporting programs that can improve the quality of learning in Islamic Senior High School of Surabaya have been intensively socialized by familiarizing themselves with religious activities (habituation of Dhuha prayers, reading the Koran at zero hours, praying Dhuhr and Asr in the congregation, habituation of prayer. The beginning and end of learning are guided by students who have been appointed in turns. In line with Puspitasari' (2017) that to improve academic quality assurance of education requires good refraction in attitude or daily morals in learning. The explanation above is some samples of interview exposure have been done by researchers in analyzing the implementation of quality assurance in Islamic Senior High School of Surabaya, Next will be given some samples of quality assurance interviews in Islamic Senior High School of 2 Malang.

After conducting interviews, observations, and in-depth studies on quality assurance of the two Madrasahs, several interviews were obtained that were given by research participants. For example, the head of the regional office of the Ministry of Religion of East Java Province gave his opinion regarding the existence of the Islamic Senior High School of 2 Malang that.

"State Madrasah Aliyah throughout East Java was helped by the existence of Islamic Senior High School of 2 Malang. Lots of achievements were made. This is because the system built is good, the learning methods have been updated, the teachers are also qualified. Many of the students became ambassadors for the science Olympiad held by the Ministry of Education and Culture." 
Implementation of Islamic Senior Hight School Academic Quality Assurance (Multi-Site Study at Islamic Senior High School of Surabaya and Islamic Senior High School of 2 Malang)

The trust given by the Regional Office of the Ministry of Religion of East Java Province by Islamic Senior High School of 2 Malang is manifested by the achievement of various academic achievements. This can be achieved because the trust given by the Madrasah Principals is fully implemented by each person in charge of the national education standards, especially regarding academic quality standards. It is in line with the research by Musa (2019) states that to obtain good quality assurance, it is important in defining the quality of the rank and achievement of a university or school. It is also by Odongo 2017 which states that academic achievement supports high-quality assurance of education.

Islamic Senior High School of 2 Malang also conducts socialization program activities incentively to achieve graduates who are by SKL. As in the guidelines for the curriculum document of Islamic Senior High School of 2 Malang, it is stated that students undergo various activities as an integral and quality learning process and have a quality attitude of knowledge and skills. This description is by the results of the documentation of the Islamic Senior High School of 2 Malang activity program.

Islamic Senior High School of 2 Malang also fosters teachers to be more professional by including them in various activities to increase teacher competence. This was conveyed by Mr. Sujito as the vice president of the Islamic Senior High School of 2 Malang curriculum as follows,

"One of the important things that affect the quality of education is the capacity and competence of existing teachers. So that Islamic Senior High School of 2 Malang routinely and continuously conducts Professional and Mental Career Development (Binkarsikal) by attending various workshops, training, or educational development seminars according to their subjects. Besides, it provides opportunities for all teachers to carry out further studies at the undergraduate, postgraduate, and doctoral levels. Most of the teachers have joined this program."

From the results of the interview above, it shows the commitment of Islamic Senior High School of 2 Malang City which encourages all teachers to have the personal, social, and technical competence of educational personnel by the Minister of Education Regulation No. 24 so that the quality of education in Islamic Senior High School of 2 Malang increases. By research from Musa (2019), it is stated that to obtain academic quality assurance a Madrasah or college continues to develop the human resource capacity of educators through fostering workshops, increasing scientific activities (Tennant et al., 2016; Rokhmana et al., 2014), publishing journals, and providing additional funds for research activities. As well as continuing to encourage to continue studying at university (Sanga \& Ahn, 2014).

Based on the explanation of the interview results above, it can be obtained tabulation of the data findings between the two Islamic Senior High School of Surabaya and Islamic Senior High School of 2 Malang as follows:

Table 1. Findings of the implementation of academic quality assurance in Islamic Senior High School of Surabaya.

\begin{tabular}{lll}
\hline No & Findings & Findings Notes \\
\hline
\end{tabular}


Implementation of Islamic Senior Hight School Academic Quality Assurance (Multi-Site Study at Islamic Senior High School of Surabaya and Islamic Senior High School of 2 Malang)

1 Giving confidence in the implementation of quality assurance

2 The madrasah activity program is intensively socialized

3 Preparation of Learning Devices
1. Giving confidence in the im1. Establish a person in charge of each national education standard

2. Using the 2013 curriculum

3. Review of curriculum and management in learning implementation of quality assurance

1. Habit in improving the quality of learning through activities

2. Design involves many components in learning

1. Lesson Plan is designed collaboratively by a group of teachers who are members of the team

2. Outreach and training in the MGMP team

3. Lesson Plan is prepared through the formulation and determination of teamwork of subject teachers together

Table 2. Findings of the implementation of academic quality assurance in Islamic Senior High School of 2 Malang.

\begin{tabular}{|c|c|c|}
\hline No & Finding & Note of Finding \\
\hline 1 & $\begin{array}{l}\text { Giving confidence in the } \\
\text { implementation of quality } \\
\text { assurance }\end{array}$ & $\begin{array}{l}\text { 1. The team responsible for each standard to support } \\
\text { learning } \\
\text { 2. The design of Lesson Plan is always being } \\
\text { improved } \\
\text { 3. Establish a field of improvement and quality } \\
\text { assurance of madrasah (P2MM) }\end{array}$ \\
\hline 2 & $\begin{array}{l}\text { The madrasah activity } \\
\text { program is intensively } \\
\text { socialized }\end{array}$ & $\begin{array}{l}\text { 1. Habit in improving the quality of learning through } \\
\text { religious activities } \\
\text { 2. Quality learning activity programs are always } \\
\text { optimized } \\
\text { 3. Increased communication and interaction as a } \\
\text { group }\end{array}$ \\
\hline 3 & $\begin{array}{l}\text { Preparation of Learning } \\
\text { Devices }\end{array}$ & $\begin{array}{l}\text { 1. Lesson Plan is designed collaboratively by a team } \\
\text { of teachers } \\
\text { 2. Socialization of learning device innovations } \\
\text { 3. Lesson Plan is prepared through the formulation } \\
\text { and determination of joint work }\end{array}$ \\
\hline
\end{tabular}

Based on the analysis of the second Madrasah site, a cross-site analysis of the implementation of Madrasah academic quality assurance will be obtained as follows:

Table 3. Cross-site analysis of Madrasah academic quality assurance implementation.

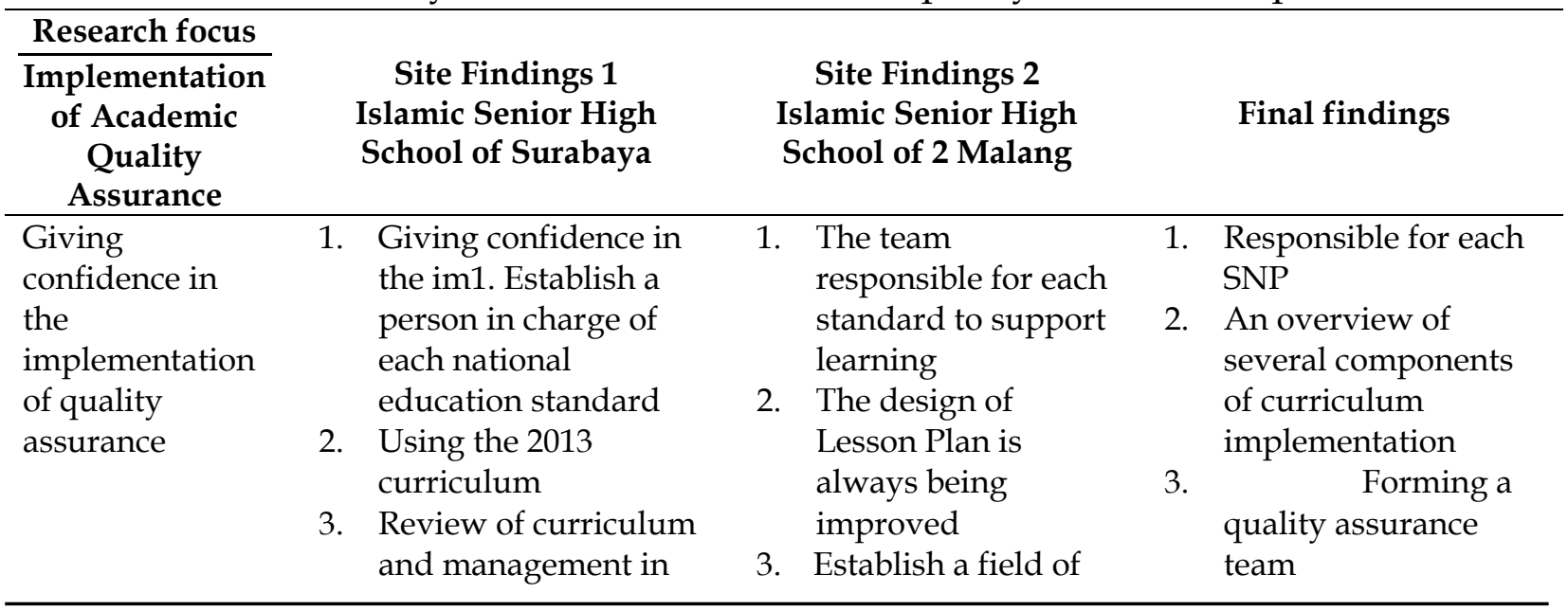




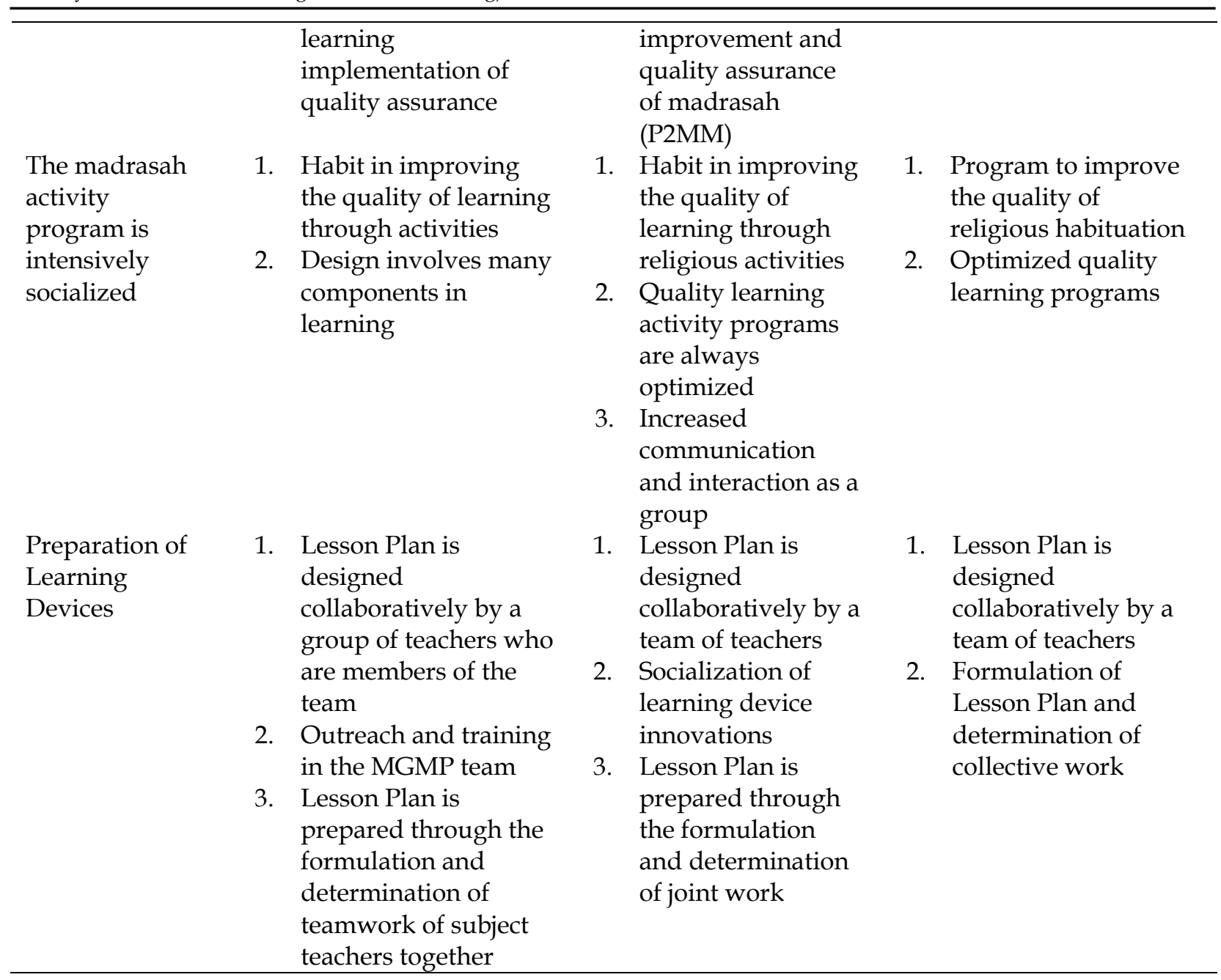

Based on the comparison in the implementation of academic quality assurance at Islamic Senior High School of Surabaya and Islamic Senior High School of 2 Malang. So it can be taken a meeting point for the results of the cross-site analysis, namely 1) Madrasah leaders give confidence and responsibility to implement management guidelines, always striving for the formation of team teaching in learning. Supported by Anwar (2018) that efforts to improve the quality of education need to also improve the competence of madrasah principals. The leader determines how to improve the quality of academic assurance (Budiarto et al., 2018; Musa, 2019; Nawawi, 2020). 2) Madrasahs have full quality assurance management guidelines, conduct a review of the curriculum and management of learning, and the design of lesson plans is still simple and needs improvement. The academic quality assurance planning document has been implemented in the learning process (Puspitasari, 2017; Mulyasa et al., 2018). 3) The madrasah activity program is always maximally socialized, habituation in improving the quality of learning through activities, and quality learning (Puspitasari, 2017; Sukandari, 2016), 4) The madrasah activity program is still maximally socialized (Anwar, 2018), design involves many components in learning, design ranging from material to evaluation (Puspitasari, 2017; Leiber et al., 2015), and improvement in communicating and interacting as a group which is always maximized, and also 
Implementation of Islamic Senior Hight School Academic Quality Assurance (Multi-Site Study at Islamic Senior High School of Surabaya and Islamic Senior High School of 2 Malang)

support in developing the quality of school quality assurance (Seyfried \& Pohlenz, 2018; Zhao et al., 2012).

\section{Implementation of Academic Quality Assurance in Madrasah}

The implementation of academic quality assurance is carried out by providing trust and responsibility, socializing madrasah activities, and preparing learning tools. Madrasah leaders give confidence and responsibility in implementing quality management guidelines by forming an effective teaching team in learning and a team responsible for national education standards. This concurs with Sallis (2012) which states that the fundamental step in a quality program is a management committee that is crucial to success and is the main point that has been agreed upon by all quality experts, quality initiatives. should be directed and led by senior management. In line with research from Nawawi (2020), it is stated that the quality of education is measured by the leader, as well as in his leadership commitment (Suryaningsih et al., 2019; Saihu, 2019).

The findings of research related to giving trust and responsibility in implementing quality management guidelines in Islamic Senior High School of 2 Malang have the same as the findings in Islamic Senior High School of Surabaya, namely giving trust by forming a team responsible for each national education standard. Meanwhile, what distinguishes Islamic Senior High School of 2 Malang, the Head of Madrasah forms the Madrasah Quality Assurance and Development Sector (P2MM) which consists of several educators. This P2MM manages madrasah quality assurance to ensure that the quality of education can be maintained and improved as planned (Haryono et al., 2019).

From the research findings, Madrasah Islamic Senior High School of 2 Malang has succeeded in achieving academic quality that exceeds the national education standards and has become a model madrasah that has achieved various extraordinary achievements, both in competitions and at the regional and even national level Olympics. Based on the explanation above, the researcher supports the theory of Sallis (2012) which states that good leadership is delegating responsibility and authority for each task to an organizational sub-unit.

In the findings of subsequent research, Islamic Senior High School of Surabaya and Islamic Senior High School of 2 Malang, various programs of Islamic madrasah activities are always socialized intensively to support the achievement of quality learning outcomes. The findings of research in Islamic Senior High School of Surabaya and Islamic Senior High School of 2 Malang also revealed that the preparation of learning tools was carried out by designing a Learning Implementation Plan, socialization of various activity programs and preparation of learning devices must be by the quality standards of learning in their implementation, always being developed and improved.

Related to the efforts to prepare learning devices at two madrasas, namely Islamic Senior High School of Surabaya and Islamic Senior High School of 2 Malang, it shows similarities, the preparation of learning tools in madrasas is done by compiling a learning implementation plan carried out by educators collaboratively through a group of teachers who are members of the team before the implementation of the open lesson.

The findings from research in Islamic Senior High School of 2 Malang give trust and responsibility to implement guidelines for management of academic quality management carried out in an organized, systematic and comprehensive manner. The 
Subject Teacher Deliberation Team (MGMP) is responsible for the success of learning in the classroom. In this case, the purpose of the learning design is carried out so that the learning material is clear and directed, adjusted to the applicable learning implementation standards to achieve the learning objectives, namely improving the quality of learning. The implementation of quality improvement that has been carried out by Islamic Senior High School of Surabaya and Islamic Senior High School of 2 Malang in improving academic quality is relevant to Sanga \& Ahn (2014) theory which states that quality or quality has varying definitions ranging from conventional to more strategic. In this case, it is also supported by Haryono et al., (2019) that an education quality assurance system must be implemented to build a culture of continuous quality improvement in schools. As well as improving the quality of academic education continues to be improved and maintained (Musa, 2019; Sulaiman \& Wibowo, 2016; Kane et al., 2017).

\section{Implementation Strategy of Madrasah Academic Quality Assurance}

The first strategy of academic quality assurance needs to be done by in addition to forming social attitudes and devotion of students, also in educating students so that students have maximum achievements in both academic scores and achieve success in various competitions on a national scale, the second is in developing potential students in achieving the best performance, madrasas cannot do it alone, but also involve the participation of various parties, ranging from teaching staff (team teaching), students, student guardians and related institutions that support the success of madrasas. Below will be given a schematic diagram of the implementation of Quality Assurance.

Based on the quality assurance implementation strategy described above, it is in line with research from Mulyasa et al., (2018) which states that the formation of education quality through self-development provides an academic standard quality assurance assessment. Then it is also supported by Tennatn et al., (2016) and Odongo (2017) to provide a statement that working in team work can improve academic performance and the quality of education. 


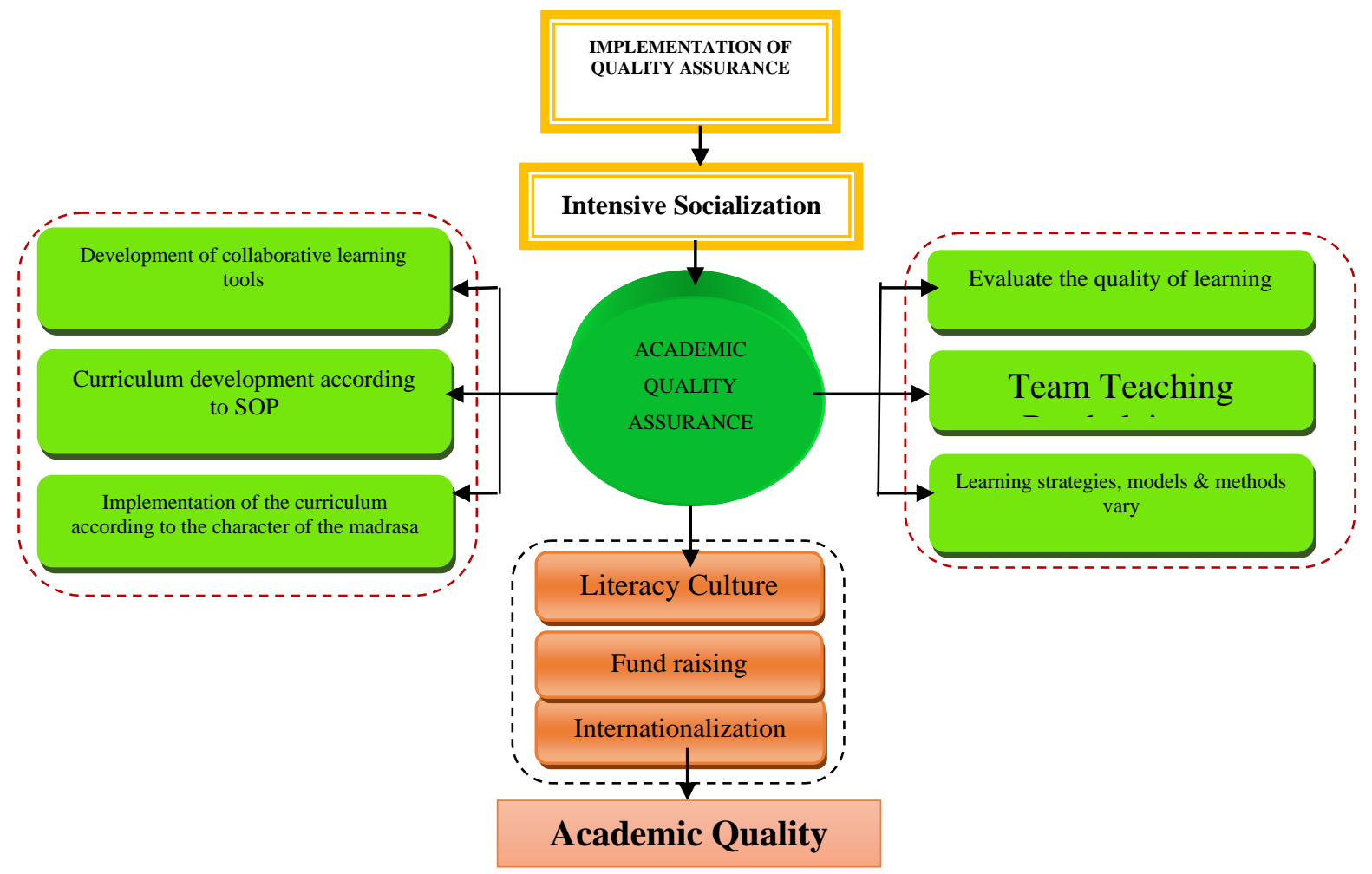

Figure 1. Conceptual recommendations for the implementation of academic quality assurance.

From the picture, conceptual recommendations are designed and developed based on the theoretical studies that have been carried out and adjusted to the findings of research in the field. Then the conceptual recommendation chart above can be explained that the quality assurance used in the two research locus settings is to implement an appropriate madrasah academic quality assurance strategy by implementing madrasah quality assurance, the implementation of madrasah quality assurance is carried out by establishing a Madrasah quality assurance institution, following Kennedy (2014) which states that in building quality, quality awareness must be fostered (Quality Awareness), namely an effort to raise awareness of everyone in the organization and the necessity to implement the proclaimed program (Wahyudi et al., 2020). With the existence of an internal quality assurance team at the madrasah, awareness will emerge on all components in the madrasah. Meanwhile, the reference used in the implementation of quality assurance is to use the 8 national education standards criteria.

\section{CONCLUSIONS}

Based on the results of the research that has been done, it can be concluded that the implementation of academic quality assurance in the process of implementing education at Madrasahs has been carried out well in improving the quality of learning, academic achievement, and competitiveness of these madrasah graduates. The implementation of quality assurance can be done using the first strategy, the leadership has given trust and responsibility in implementing management guidelines, second, the 
madrasah activity program is socialized intensively, and third, the preparation of learning tools that are carried out collaboratively. Overall, the implementation of madrasah academic quality assurance has been carried out according to national education standards. But because of the variety of learning inputs (students), the quality of learning certainly cannot be the same.

\section{ACKNOWLEDGEMENTS}

The research team would like to thank all leaders at the Faculty of Education Management, Surabaya State University, for providing the opportunity to conduct research related to academic quality assurance.

\section{REFERENCES}

Aelterman, N., Vansteenkiste, M., Van, K.H., Meyer, D.J., Berghe, V.D.L., \& Haerens, L. (2013). Development and evaluation of a training on need-supportive teaching in physical education: Qualitative and quantitative findings. Teaching and Teacher Education, 29, 64-75.

Anwar, K. (2018). Peran sistem penjaminan mutu pendidikan dalam meningkatkan mutu pendidikan di madrasah. Jurnal Pendidikan Agama Islam, 1(1), 41-56.

Budiarto, G., Yulianda, F., \& Zulbainarni, N. (2018). Strategi sinkronisasi implementasi Sistem Penjaminan Mutu Internal (SPMI) dengan ISO 9001 program sarjana IPB. Jurnal Aplikasi Manajemen dan Bisnis, 4(2), 102-211.

Darmaji., Supriyanto, A., \& Timan, Agus. (2019). Sistem penjaminan mutu internal sekolah untuk meningkatkan mutu lulusan. Jurnal Manajemen dan Supervial Pendidikan, 3(3), 130-137.

Goldhaber, D. (2015). Exploring the potential of value-added performance measures to affect the quality of the teacher workforce. Educational Researcher, 44(2), 87-95.

Gore, J. M., \& Bowe, J. M. (2015). Interrupting attrition? Re-shaping the transition from preservice to inservice teaching through Quality Teaching Rounds. International Journal of Educational Research, 73, 77-88.

Handayani, S., \& Pujiono. (2017). Academicians satisfy of the faculty of economics, in universitas negeri surabaya throught on total quality management. AFEBI Accounting Review (AAR), 2(1), 52-63.

Haryono., Budiyono., Istyarini., Wardi., \& Ardiantoro, A. (2019). Sistem penjaminan mutu pendidikan dalam meningkatkan mutu pendidikan sekolah dasar di kecamatan gajah mungkur kota semarang. Jurnal Panja, 1(1), 17-22.

Hill, H.C., \& Beisiegel, M., \& R. Jacob. (2013). Professional development research: Consensus, crossroads, and challenges. Educational Researcher, 42(9), 476-487.

Kane, M., Frauke, M., Esther, S.Y., Christine, M., \& Rubie, D. (2017). Subjectivity of teacher judgments: Exploring student characteristics that influence teacher judgments of student ability. Teaching and Teacher Education, 65, 48-60.

Kennedy, A. (2014). Understanding continuing professional development: The need for theory to impact on policy and practice. Professional Development in Education, 40 (5), 688-697.

Leiber, T., Stensaker. B., \& Harvey, L. (2015). Impact evaluation of quality assurance in higher education: Methodology and causal designs. Quality in Higher Education, 21 (3), 288-311. 
Implementation of Islamic Senior Hight School Academic Quality Assurance (Multi-Site Study at Islamic Senior High School of Surabaya and Islamic Senior High School of 2 Malang)

Miles, H., \& Saldana. (2014). Qualitative data analysis: A metods sourcebook. Arizona State University.

Mulyasa, E., Supyan, S., \& Aryani, W.D. (2018). Strengthening of department governance through implementation of an internal quality assurance system. Advances in Social Science, Education and Humanities Research, 258, 207-211.

Musa, M. (2019). An analysis of quality assurance key performance indicators in research in Ugandan Universities. International Journal of Instruction, 12(1), 15681584.

Nawawi, M.A., \& Rudini. (2020). Implementasi kepemimpinan dalam peningkatan sistem penjaminan mutu internal pada Sekolah Tinggi Agama Islam Kharisma Cicurug Sukabumi. Jurnal Pendidikan Islam, 2(1), 42-65.

Nuraeni, Y. (2010). Perancangan sistem informasi penjaminan mutu perguruan tinggi bidang sumber daya manusia. Journal of Information, 6(1), 32-43.

Odongo, R. (2017). Standards and Guidelines for Quality Assurance in Higher Education in Africa. Riga: Latvia.

Oztas, A., Ozdemir, M., Mart, C.T. (2017). Perspectives on quality assurance in higher education in Iraq: A case study at Ishik University. International Journal of Academic Research in Business and Social Sciences, 7(9), 269-272.

Puspitasari, H. (2017). Standar proses pembelajaran sebagai sistem penjaminan mutu internal di sekolah. Muslim Heritage, 1(2), 339-368.

Rokhmana, F., Humb, M., Syaifudinc, A., \& Yuliatid. (2014). Character education for golden generation 2045 (National Character Building for Indonesian Golden Years). Procedia Social and Behavioral Sciences, 141(25), 1161-1165.

Saihu. (2019). Implementasi manajemen balanced scorecard di pondok pesantren Jam'iyyah Islamiyyah Tangerang Selatan. Mumtaz, 3(1), 1-22.

Sallis, E. (2012). Total quality management in education. Yogyakarta: IRCiSoD.

Sanga, P.L., \& Ahn, M.L. (2014). Challenges and opportunities for quality assurance of cross-border higher education: The case of East Africa. Journal of Emerging Trends in Educational Research and Policy Studies, 5(1), 126-132.

Seyfried, M., \& Pohlenz, P. (2018) Assessing quality assurance in higher education: quality managers' perceptions of effectiveness. European Journal of Higher Education, 8(3), 258-271.

Sugiyono. (2018). Metode penelitian kuantitatif, kualitatif, dan R\&D. Bandung: Alfabeta.

Sukandari, E., \& Nuryana, I.K.D. (2016). Rancang bangun sistem informasi unit penjaminan mutu (UJM) teknik informatika Di Universitas Negeri Surabaya. Jurnal Manajemen Informatika, 5(1), 37-45.

Sulaiman, A., \& Wibowo, U.B. (2016). Implementasi sistem penjaminan mutu internal sebagai upaya meningkatkan mutu pendidikan di Universitas Gadjah Mada. Jurnal Akuntabilitas Manajemen Pendidikan, 4(1), 17-16.

Suryaningsih, T., \& Imron, A. (2019). Komitmen pimpinan dalam implementasi sistem penjaminan mutu akademik perguruan tinggi (studi kasus pada STKIP PGRI Tulungagung). Jurnal Penjamin Mutu, 5(1), 109-118.

Suwardani, N.P. (2010). Implementasi kebijakan rintisan sekolah bertaraf internasional (Studi multisitus pada tiga sekolah menengah atas negeri di Bali). Jurnal Pendidikan Dan Pembelajaran, 17(1), 1-10. 
Tennant, J.O., Waldner, F., Jacques, D.C., Masuzzo, P., Collister, L.B., \& Hartgerink, C.H.J. (2016). The academic, economic and societal impacts of open access: An evidence-based review. Research Open for Science, 5, 623.

Wahyudi, I., Fuadi, I., Naim, N., Muhajir, A., Maftukhin., \& Akhyak. (2020). Implementation of curriculum in enhancing the quality of education at SMAN 1 Blitar and MAN 2 KEDIRI. Internasional Journal of Arts and Commerce, 9(3), 13-20.

Zhao., Jing., \& Gallant, D.J. (2012). Student evaluation of instruction in higher education: Exploring issues of validity and reliability. Assessment and Evaluation in Higher Education, 37 (2), 227-235.

\footnotetext{
*Andiek Widodo (Corresponding Author)

Doctoral Program of Education Technology

Universitas Negeri Surabaya

Jl. Raya Kampus Unesa, Lidah Wetan, Kec. Lakarsantri, Surabaya, Indonesia

Email: andiekwidodo16070976007@mhs.unesa.ac.id
}

\section{Prof. Dr. Yatim Riyanto}

Universitas Negeri Surabaya

Jl. Raya Kampus Unesa, Lidah Wetan, Kec. Lakarsantri, Surabaya, Indonesia

Email: yatimriyanto@unesa.ac.id

\section{Dr. Erni Roesminingsih}

Universitas Negeri Surabaya

Jl. Raya Kampus Unesa, Lidah Wetan, Kec. Lakarsantri, Surabaya, Indonesia

Email: ernyroesminingsih@unesa.ac.id 